\title{
Research on the Relationship Between the Volume of Shenzhen Stock Market and Economic Growth
}

\author{
Guanglu $\mathrm{Li}^{1 *}$ Susheng Wang ${ }^{1}$ \\ ${ }^{1}$ School of economics and management, Harbin Institute of Technology (Shenzhen), ShenZhen, GuangDong 518055, \\ China \\ *Corresponding author. Email: 407995864@qq.com
}

\begin{abstract}
In 2019, the trading volume of Shenzhen stock market increased by $46.38 \%$, which contributing $0.1 \%$ to China's GDP growth, $0.41 \%$ to Guangdong's GDP growth and $0.30 \%$ to Shenzhen's GDP growth. The impact of the turnover of stock market on economic growth is different in different stages of the development of stock market in China. Under the current economic situation, the turnover of stock market is highly positively related to economic growth. According to the impact of turnover growth on the growth of financial industry, the result of estimating the growth of turnover growth on GDP growth in Shenzhen stock market shows that every doubling of turnover growth in Shenzhen stock market can contribute $0.24 \%$ to China's GDP growth, $0.93 \%$ to Guangdong's GDP growth, and $0.60 \%$ to Shenzhen's GDP growth. From the perspective of the development of the securities market, moderately prosperous stock market can improve the efficiency of market resource allocation, expand the scale of corporate direct financing and enhance the expected economic growth, and promote the development of the real economy. The over booming stock market will not only cause crowding out of savings, but also lead to stock market bubbles, increase market risk exposure, and endanger financial stability.
\end{abstract}

Keywords: volume, Shenzhen stock market, the GDP growth, over booming stock market, crowding out effect

\section{INTRODUCTION}

The impact of the development of stock market on the real economic growth is not fixed, but determined by the characteristics of the economic development and its development stage. In the past, some studies on the stock market in developed countries have shown that the enhancement of stock market liquidity can effectively reduce the cost of market transactions and information acquisition, realize the effective allocation of resources, and stimulate the growth of the real economy. In 2019, the turnover of China's stock market increased significantly, with a total turnover of 127.41 trillion yuan, a year-on-year increase of $41.95 \%$. In the same period, China's GDP reached 99.09 trillion yuan, a year-on-year increase of $6.1 \%$. Under the current economic situation, the contribution of stock market turnover growth to China's economic growth is worth studying.

According to the traditional growth theory, investment quantity and efficiency are the key factors to achieve rapid economic growth, and the saving rate and market resource allocation play an important role in economic growth. From the perspective of influencing economic growth, the growth of stock turnover can enhance market liquidity; reduce the cost of information acquisition and other ways to improve the efficiency of market resource allocation, so as to achieve the promotion of economic growth. In the past 40 years of reform and opening up, China's economy has maintained rapid growth. During this period, the stock market has experienced three stages of development from scratch. The impact of trading volume of Shenzhen stock market on economic growth is different in different stages of development.

In the initial stage of stock market, the turnover of Shenzhen stock market has little effect on economic growth. During the initial period of stock market (1991-1995), the outstanding characteristics of stock market are lack of supervision, incomplete system and sharp rise and fall of stock market. In the exploration of market trading rules and regulatory measures, the performance of the stock market is independent of the macroeconomic trend, showing a typical policy market, and even the famous "810" event broke out, which severely hit the development of the stock market at that time. At this stage, the correlation coefficient between turnover and GDP in Shenzhen stock market is 0.59, but the average turnover only accounts for $2.3 \%$ of GDP, which has little impact on the economic development at that time.

During the period of stock market consolidation, the turnover of Shenzhen stock market is negatively related to GDP. After the initial pains, the stock market ushered in the period of consolidation (1996-2003). With the implementation of a series of measures, such as the limit of price limit, the promulgation of securities law, the introduction of social security fund, the establishment of QFII system and the reform of non-tradable shares which has a significant impact on the stock market, the stock market has gradually standardized. The sharp rise and fall of the policy market is still the prominent feature of this 
stage, among which the state-owned enterprises have the greatest impact on the market volatility through the introduction and tightening of the stock market reduction policy. At this stage, the stock market is still difficult to reflect the development of macro-economy. The correlation coefficient between the turnover of Shenzhen stock market and GDP is -0.16 .

In the period of orderly development of stock market, the turnover of Shenzhen stock market is positively related to GDP. With the gradual completion of the split share structure reform, the stock market ushered in an orderly development period (2004-2019). Although there are still some reform measures that have a great impact on the market, such as the establishment of the small and mediumsized board, the venture edition, the Shanghai Hong Kong stock connect, the implementation of the Shenzhen Hong Kong stock connect business, the promotion of margin trading business, and the reform of the registration system, etc., the basic trading system of the stock market remains unchanged, and the market has ushered in two bull sessions city, volume is climbing. During this period, the turnover of Shenzhen stock market was highly positively correlated with GDP, with a correlation coefficient of 0.76 .

\subsection{Related Work}

In the past, some empirical studies have found evidence of positive correlation between stock market development and economic growth. Atje and Jovanovic [1993] confirmed that there is a strong correlation between the development of the stock market and the growth rate of real GDP per capita, and the liquidity of the stock market has a strong ability to predict the future economic growth rate. Alovsat and Tuncer [2000] verify that there is a positive correlation between the development of the stock market and the level of economic activity. Bahadur and Neupane [2006] found that market volatility can predict future economic growth rate, but causality only exists between actual indicators. Agrawalla and Tuteja [2007], respectively, based on the data of the United States, Ghana, Pakistan, India and other countries, verified the role of stock market development in promoting economic growth.

Duan Hongbin and Yang Guang [2009] found through Granger causality test that there is a two-way causality between capitalization rate and economic growth. Turnover rate is the Granger cause of economic growth, and economic growth is the Granger cause of transaction rate. They believed that economic growth can promote the development of stock market, and the development of stock market can further promote economic growth.

\subsection{Paper Structure}

The rest of the paper is organized as follows. Section 2 introduces the method used in this paper, Sample selection and Empirical test results. Then, concludes in Section 3.

\section{METHOD}

\subsection{Probabilistic Automata}

The core of this method is to calculate the quantitative relationship between the growth of stock turnover and the growth of GDP, which is the representative variable of the growth of securities industry. China's financial GDP statistics mainly include banking, securities and insurance. We use the growth rate of stock transaction amount, deposit and loan balance and premium to represent the growth rate of securities industry, banking industry and insurance industry respectively. We use these three variables as explanatory variables of GDP growth of financial industry, Guangdong financial industry and Shenzhen financial industry respectively. Through regression method, the quantitative relationship between the growth rate of stock turnover and the growth rate of GDP of financial industry is calculated, and then the contribution of the growth rate of stock turnover to the growth rate of GDP is indirectly calculated by using the quantitative relationship between the GDP of financial industry and GDP.

Specifically, when calculating the growth rate of industry GDP, we generally divide it into two steps: the first step is to convert the growth rate of the sub industry GDP according to the growth rate indicators corresponding to the target industry GDP to be calculated; the second step is to weighted and average the growth rate of the micro industry GDP to get the growth rate of the large industry in the GDP accounting.

According to the above steps, we use $S_{i}$ to represent the GDP growth of the financial industry of i-th season, $\mathrm{X}_{i}, Y_{i}, Z_{i}$ represent the loan balance growth, premium income growth and stock turnover growth respectively, $\omega_{1}, \omega_{2}, \omega_{3}$ represent the conversion coefficient of corresponding indicators, and $\varphi_{1}, \varphi_{2}, \varphi_{3}$ represent the weight of corresponding indicators, so we can express the GDP growth of i-th season as follows:

$$
\mathrm{S}_{i}=\varphi_{1} \omega_{1} \mathrm{X}_{i}+\varphi_{2} \omega_{2} Y_{i}+\varphi_{3} \omega_{3} Z_{i}
$$

In the above formula, both the conversion coefficient and the weight are unknown data, but we can regard $\varphi_{i} \omega_{i}$ as a whole coefficient, and use the historical quarterly data to regress it to get: 


$$
\mathrm{S}_{i}=\alpha \mathrm{X}_{i}+\beta Y_{i}+\gamma Z_{i}
$$

of the correlation coefficient between the year-on-year growth of Shenzhen transaction amount and the GDP of the financial industry are as follows:

Among them, $\alpha, \beta, \gamma$ represent the growth coefficients of quarterly loan balance, premium income and stock turnover respectively. Through the regression of historical data, we can obtain stable model coefficients, so that we can accurately calculate the impact on GDP growth according to the change of transaction amount in the current stock market.

Sample selection and empirical test: We select 62 sample data of the highest frequency from the first quarter of 2004 to the second quarter of 2019 as the research object. The corresponding variables are: the year-on-year growth of Shenzhen stock turnover, the year-on-year growth of bank deposits and loans, the year-on-year growth of insurance premiums, the year-on-year growth of China's financial industry GDP, Guangdong's financial industry GDP and Shenzhen's financial industry GDP. The regression results
There is a significant positive correlation between the growth rate of turnover amount of Shenzhen stock market and the GDP growth rate of financial industry in different administrative regions. The past data research shows that the growth rate of transaction amount in Shenzhen stock market is positively related to the GDP growth of financial industry in China, Guangdong and Shenzhen. The estimated coefficients for the growth of financial industry in different regions are $2.8 \%, 10.8 \%$ and $4.7 \%$ respectively. That is to say, for every double of the year-on-year growth rate of the turnover amount in Shenzhen stock market, it will China's financial industry, Guangdong's financial industry and Shenzhen's financial industry respectively. contribute $2.8 \%, 10.8 \%$ and $4.7 \%$ to the GDP growth of

Table 1 Regression results of correlation coefficients

\begin{tabular}{|c|c|c|c|c|c|}
\hline Variable & Coefficients & St & t-Value & P-Value & Significance \\
\hline Financial GDP growth & 0.028 & 0.004 & 7.205 & $1.33 \mathrm{e}-09$ & $* * *$ \\
\hline $\begin{array}{c}\text { GDP growth of Guangdong } \\
\text { financial }\end{array}$ & 0.108 & 0.025 & 4.350 & $5.59 \mathrm{e}-05$ & $* * *$ \\
\hline $\begin{array}{c}\text { GDP growth of Shenzhen } \\
\text { financial }\end{array}$ & 0.047 & 0.016 & 2.954 & 0.005 & $* *$ \\
\hline
\end{tabular}

In 2019, the increase of transaction amount in Shenzhen stock market contributed $0.1 \%$ to the year-on-year growth of China's GDP, $0.41 \%$ to the year-on-year growth of Guangdong's GDP and $0.30 \%$ to the growth of Shenzhen's GDP. Last year, the turnover of Shenzhen stock market reached 72.79 trillion yuan, an increase of $46.38 \%$ year on year. During the same period, China's GDP reached 99.09 trillion yuan, accounting for $7.8 \%$ of the added value of the financial industry; Guangdong's GDP reached 10.77 trillion yuan, accounting for $8.25 \%$ of the total; Shenzhen's GDP reached 2.69 trillion yuan, accounting for $13.7 \%$ of the total. According to the above calculation method of the impact on GDP growth, we calculated the change results of GDP growth and GDP growth of financial industry caused by the year-on-year increase of $46.38 \%$ of the turnover amount of Shenzhen stock in 2019 as follows:

Table 2 Contribution results

\begin{tabular}{|c|c|c|c|}
\hline $\begin{array}{c}\text { Changes of turnover growth of Shenzhen Stock } \\
\text { Market }\end{array}$ & China & Guangdong & Shenzhen \\
\hline GDP growth & $6.1 \%$ & $6.2 \%$ & $6.7 \%$ \\
\hline Contribution to GDP growth of financial industry & $1.30 \%$ & $5.01 \%$ & $2.18 \%$ \\
\hline Contribution to GDP growth & $0.10 \%$ & $0.41 \%$ & $0.30 \%$ \\
\hline
\end{tabular}

The contribution of turnover growth to GDP is mainly reflected in the improvement of resource allocation efficiency in the stock market and the growth of GDP in the securities industry.
On the one hand, information asymmetry will produce adverse selection and moral hazard, which will affect the effective allocation of resources. High information cost is an important factor that affects the optimal allocation of resources. The stock market helps investors distinguish the 
advantages and disadvantages of investment opportunities through its effective secondary market stock price, reduces the transaction cost of capital allocation, and improves its allocation efficiency. With the increase of stock market liquidity, investors can get information of the company according to the past price of the stock. It is because of the profitability of information that investors will collect company information and supervise the operation of the company, which will improve the allocation of resources and promote economic growth.

On the other hand, the increase of stock turnover can increase the added value of securities enterprises from two aspects, and then promote the growth of financial GDP. First, the large increase of stock trading volume helps to improve the brokerage business income of securities companies. The large increase of turnover in the stock market and the increase of brokerage business income will help to enhance the added value of securities companies. In 2019, the net income of brokerage business of securities companies reached 78.8 billion yuan, accounting for $22 \%$ of the total income, an increase of $26 \%$ year on year. Second, the large increase of stock trading volume helps to improve the self-operating business income of securities companies. As a professional investor in the market, securities companies rely on strong investment and research capabilities, and the level of self-operation is constantly improving. However, the sharp change of trading volume in the stock market is often accompanied by the sharp fluctuation of the market, which is conducive to further improving the self-operating business income of securities companies. In 2019, the securities investment income of securities companies reached 122.2 billion yuan, accounting for $34 \%$ of the total income, an increase of $53 \%$ year on year.

The contribution of turnover growth to GDP is not enough to reflect the full contribution of Shenzhen to economic growth. First, the turnover of shares failed to reflect the contribution of direct financing in Shenzhen to economic growth. In 2019, the financing amount of Shenzhen stock market was 508.9 billion yuan, and the financing amount of fixed income products exceeded 1.7 trillion yuan, effectively supporting the development of the real economy. Second, the volume of stock transactions failed to measure the impact of the venture capital system formed under the influence of Shenzhen stock market on economic growth. The existence of the exchange provides an effective exit mechanism for venture capital and has a profound impact on the development of venture capital enterprises. In 2019, venture capital invested 678.6 billion yuan, which greatly promoted the development of China's new economy. Third, the turnover of shares failed to reflect the long-term effect of Shenzhen stock market on the business performance and the transformation of business mechanism. Finally, the change of stock turnover only reflects the promotion of market resource allocation efficiency to economic growth, and does not fully reflect the key role of market resource allocation played by Shenzhen stock market in economic development.

The prosperity degree of the stock market should meet the needs of the development of the real economy, and prevent the economy from getting rid of the real to the virtual. Too much liquidity in the stock market may reduce the saving rate, but it will reduce the economic growth rate. From the perspective of historical data, overheated stock market tends to squeeze out savings and weaken the financing function of capital market. From the trend of trading volume growth and national savings rate growth of Shenzhen stock market in the past 15 years (Figure 1), the stock market experienced three periods of substantial increase in trading volume in 2007, 2009 and 2015, and the national total savings rate decreased to varying degrees. Too high trading volume of stock has a certain crowding out effect on savings. In addition, the overheated stock market is often accompanied by the market valuation system disorder, the loss of pricing function and the formation of stock market bubbles. Once the stock market bubble bursts, the market risk will be released rapidly, which will not only impede the normal functioning of the securities market, but also further spread the risk to the real economy, resulting in difficulties in the operation of entities, the collapse of enterprises, and the surge in unemployment. It is harmful to the healthy development of the real economy.

\section{CONCLUSION}

From the perspective of the past development of the securities market, a properly prosperous securities market can not only reduce the market information asymmetry, but also reduce the financing difficulty of enterprises, improve the efficiency of market resource allocation, stimulate the real investment and enhance the confidence of economic development. The highly prosperous market is generally highly speculative, which will not only cause capital to idle in the financial system, but also blow up the stock market bubble, aggravate financial risk exposure, endanger financial stability and other adverse effects, and adversely affect the growth of the real economy.

\section{REFERENCES}

[1] Atje R, B. Jovanovic. Stock Markets and Development[J]. European Economic Review, 1993, 37:632-640

[2]Alovsat M, G C Tuncer. Stock Markets and EconomicGrowth: A Casualty Test[J]. Dogus UniversityJournal, 2000, 2: 124-132.

[3] C. Baier, J-P. Katoen, Principles of Model Checking, MIT Press, 2008.

[4] Bahadur G C, S Neupane. Stock Market andEconomic Development: a Causality Test[J]. The Journalof Nepalese Business Studies, 2006, 3(1): 36-44.

[5] Agrawalla R K S K Tuteja. Causality BetweenStock Market Development and Economic Growth : ACase 
Study of India[J]. Journal of Management Research,2007, 7: 158-168.

[6] Duan Hongbin, Yang Guang. Stock market and economic growth: An Empirical Analysis Based on China $[\mathrm{J}]$. Journal of Central University of Finance and economics, 2009 (12): 0-0 